\title{
PLASMAPHERESIS IN THE TREATMENT OF MYASTHENIA GRAVIS
}

\section{Retrospective study of 26 patients}

\author{
Rosana Carandina-Maffeis ${ }^{1 a}$, Anamarli Nucci ${ }^{1 b}$, José F.C. Marques J r ${ }^{2 c}$, Eduardo G. Roveri ${ }^{2 d}$, Beatriz H.M. \\ Pfeilsticker ${ }^{1 c}$, Solange G. Garibaldic, Leonardo de Deus-Silva ${ }^{1 a}$
}

\begin{abstract}
We analyzed the experience of Unicamp Clinical Hospital with plasma exchange (PE) therapy in myasthenia gravis (MG). About $17.8 \%$ of a totality of MG patients had PE performed: 26 cases, 19 women and seven men. The mean age-onset of MG was 28 years, extremes 11 and 69. Minimum deficit observed in the group was graded IIb $(0 \& G)$ or Illa (M GFA scale). One patient had prethymectomy PE. In seven the procedures were performed due to myasthenic crisis and in 18 patients due to severe myasthenic symptoms or exacerbation of previous motor deficit. Two patients were also submitted to chronic PE considering refractoriness to other treatments. Twenty-six patients had 44 cycles of PE and 171 sessions. The mean number of sessions was 3.9 (SD \pm 1.4 ) each cycle; median 5, extremes 2 and 6 . The mean time by session was 106,5 minutes (SD \pm 35.2 ); median 100.5 (extremes of 55 and 215). The mean volume of plasma exchanged in each session was $2396 \mathrm{ml}(S D \pm 561$ ); median 2225 (extremes 1512 and 4500 ). Side effects occurred: reversible hypotension (seven cases), mild tremor or paresthesias (seven cases). Infection and mortality rates due to PE were zero. All patients had immediate benefit of each PE cycle and usually they also received prednisone or other immunosuppressors. Good acceptance of the procedure was observed in $80.7 \%$ of patients.
\end{abstract}

KEY WORDS: plasmapheresis, myasthenia gravis, therapeutics, acceptance, complications.

\begin{abstract}
Plasmaférese no tratamento da miastenia grave: estudo retrospectivo de 26 pacientes
RESUM 0 - Analisamos a experiência do Hospital das Clínicas da Unicamp com plasmaferese: (PF) na miastania grave (MG). 17,8 $\%$ do total dos casos de M G submeteu-se a PF, 26 casos, 19 mulheres e sete homens. A idade média de início da MG foi 28 anos (extremos 11 e 69). 0 menor déficit clínico foi llb $(0 \&$ G) e Illa (MGFA). A PF foi indicada no pré-operatório de timectomia em um caso e em sete devido a crise miastênica. Em 18 casos, com M generalizada e sintomas bulbares ou com exacerbação de déficit prévio, a PF foi indicada como intervenção aguda. Em dois pacientes desse grupo ela foi indicada também em regime crônico de ciclos mensais. Os 26 pacientes submeteram-se a 44 ciclos e a 171 sessões de PF. 0 número médio de sessões em cada ciclo foi 3,9 (DP $\pm 1,4$ ); mediana de 5, extremos 2 e 6.0 tempo médio de cada sessão foi 106,5 minutos (DP $\pm 35,2$ ); mediana de 100,5 (extremos 55 e 215).0 volume médio de plasma trocado em cada sessão foi $2396 \mathrm{ml}$ (DP \pm 561); mediana 2225 (extremos 1512 e 4500). Efeitos colaterais foram reversíveis: hipotensão (sete casos), tremor ou parestesias leves (sete casos). Taxas de infecção e mortalidade devido a PF foram zero. A totalidade dos pacientes teve benefícios imediatos a cada ciclo de PF e usualmente receberam prednisona ou outro imunossupressor. Houve boa aceitação ao procedimento em $80,7 \%$ dos pacientes.
\end{abstract}

PALAVRAS-CHAVE: plamaférese, miastenia grave, terapêutica, aceitação, complicações.

Myasthenia gravis (MG) is a well known autoimmune disease characterized by antibodies against nicotinic acetylcholine receptors and fluctuating weakness, sometimes lifethreatening ${ }^{1}$. Plasmapheresis or plasma exchange (PE) is a therapeutic modality well established in $M G^{2}$ with a positive re- commendation based on strong consensus of Class III evidence 3 . The two commonest indications for acute PE are myasthenic crisis and in the preparation for thymectomy ${ }^{3}$. Chronic PE is a term to be used when the procedure is performed on a regular basis ${ }^{4}$ for a long interval ${ }^{5}$, and it is proposed for general-

Department of Neurology ${ }^{1}$; Center for Hematology and Hemotherapy², Faculty of Medical Sciences, State University of Campinas (UNICAM P): aMD; bMD, PhD, Assistant Professor; ' MD, PhD, Assistant Physician; ${ }^{\text {BBiologist. }}$ 
ized M G refractory to other treatments ${ }^{6}$.

$P E$ is a therapeutic possibility in seropositive and seronegative forms of $\mathrm{MG}^{7}$. Its efficiency is due to removal of proteins of autoimmune biological activity, mainly antibodies to acetylcholine receptor ${ }^{8}$, leading to short-term improvement of neuromuscular junction transmission, muscular strength and motor performance ${ }^{9}$. Usually, PE is combined with immunosuppressive treatment, such as prednisone, azathioprine or both ${ }^{10,11}$, to avoid rebound effect and to maintain the improvement $^{12}$.

We analyzed our experience related to the indications, complications and outcome of PE in MG patients diagnosed and followed-up at the Neuromuscular Unit. Several aspects of the procedure itself were also retrospectively reviewed.

\section{METHOD}

We reviewed PE protocols of a consecutive series of patients from the Center of Hemotherapy and charts of MG patients attended at Unicamp Clinical Hospital. A casuistic of 26 patients was obtained. They were submitted to a total of 44 cycles and 171 sessions of PE, during 1993 to January 2002.

Clinical diagnosis of M G was complemented by laboratory exams, such as repetitive nerve stimulation tests, anti-acetylcholine receptor, anti-striational antibodies and CT images of mediastinum. Patients were classified according to the Osserman \& Genkins $(O \& G)^{13}$ and M GFA (Myasthenia Gravis Foundation of America) ${ }^{4}$ scales expressing the clinical deficit before PE. Gender, age-onset of MG, level of serum antibodies, pathological results of the thymus and the disease status in follow-up were analyzed. Immediate outcome was assessed shortly after each PE cycle. Overall outcome was based in a followup period comprising the time between the last PE cycle up to January 2002. Patients were classified according to MGFA postintervention status $^{4}$.

Continuous-flow cell separators (Dideco Vivacell BT 798 CE/A, kit 480N400 or Fresenius AS 104, kit PL1) or discontinuous-flow separator (Haemonetics MCS 3 plus, kit 980/790) machines were employed. PE was scheduled preferably in an alternate-day intervals or three consecutive days plus two alternate-days sessions. A peripheral vein access was preferred whenever possible or a centrally placed Shiley's catheter. Anticoagulation with citrate (ACD formula A), without heparin, was systematically used. Replacement of plasma removed during PE session was done with isotonic sterile saline, to make up one-half of the volume and with $4 \%$ purified human albumin to complete it. Since February $2000,4 \%$ albumin was introduced earlier in the procedure and for two-thirds of the replacement volume. A careful monitoring of hemodynamic parameters was provided and complications during or following PE were rapidly recognized and reverted by rationale interventions of medical staff that assisted the procedure and the patient. Indications for PE, number of cycles and sessions, duration of each session, volume of plasma exchanged and patient tolerance to the procedure were systematically recorded. We assumed as mandatory to do microbiological culture of catheter's extremity when it was removed.

\section{RESULTS}

Casuistic included 19 women and seven men; 19 whites and seven blacks. The mean age-onset of M G was 28 years, ranges 11 and 69 . Clinical classification based on $0 \& G$ was
IIb (16 cases), III (8 cases) and IV ( 2 cases). Using M GFA scale cases were classified as IIla (8 cases), IIIb (11 cases), IVb (2 cases) and V (5 cases). Eighteen patients were submitted to thymectomy and the histopathologic diagnosis thymus hyperplasia in eight and thymoma in two. In eight patients the gland was considered normal or exhibiting involution. An overview of our data may be seen in Table 1.

All patients responded transiently favorable to each cycle of $P E$, but none had been exclusively under this therapy. Prednisone and or azathioprine were the most frequent immunosuppressors used. PE was indicated due to myasthenic crisis in seven patients and for prethymectomy only in one. Severe motor dysfunction, especially related to bulbar signs or exacerbation of myasthenic weakness associated with corticosteroids indicated PE in 18 patients. Two patients were submitted to 6 and 5 cycles of PE respectively. A monthly schedule of two consecutive-days sessions was used and the maximum motor improvement varied from two to four weeks.

Twenty-six patients had 44 cycles of PE and a total 171 sessions. The mean number of PE sessions was 3.9 (SD \pm 1.4 ) each cycle; median of 5 (ranges 2 and 6 ). The mean time of each session was 106.5 minutes (SD \pm 35.2 ); median 100.5 (ranges 55 and 215). The mean volume of plasma exchanged was $2396 \mathrm{ml} \mathrm{(SD} \pm$ 561); median 2225, ranges 1512 and 4500. Side effects were mild and citrate dependent in seven patients. Hypotension occurred in seven cases. No catheter placing problems or infection were observed and no death occurred in consequence of PE. Good PE acceptance occurred in 80.7 $\%$ of cases.

Each cycle of PE resulted in immediate improvement of clinical status in every patient of the series. However, after the mean follow-up of 24 months (median 14.5; ranges 1 month and 8 years and 5 months), clinical status was recorded as complete stable remission (CSR) in five patients; pharmacological remission (PR) in two; minimal manifestations, taking low-dose of cholinesterase inhibitors (M M 2) in five; minimal manifestations, with low-dose cholinesterase inhibitors and some immunosuppressor (M M 3) in three; substantial decrease in clinical manifestations and reduction in medications (I) in eight; no substantial change in pretreatment clinical manifestations (U) in two. Death was registered once, but it was not directly related to PE.

\section{DISCUSSION}

PE was firstly described as a therapeutic procedure for M G in 1976 by Pinching and Peters ${ }^{14}$. During 1981-97 the disease was between the five most frequent indications for $P E$ in Canada, but the second in $1997^{15}$. A multicenter study from Taiwan showed that $34.9 \%$ of PE was indicated for MG patient ${ }^{16}$. A restricted number of national publications about $P E$ and $M G$ was encountered ${ }^{17-20}$. Seggia et al. ${ }^{17}$ from Rio de Janeiro analyzed costs and benefits of PE in the preparation 
Table 1. Summary of data from the casuistic.

\begin{tabular}{|c|c|c|c|c|c|c|c|c|c|c|c|c|c|}
\hline \multirow{2}{*}{$\begin{array}{l}\text { Case } \\
1\end{array}$} & \multirow{2}{*}{$\begin{array}{c}\text { Gender } \\
\mathrm{F}\end{array}$} & \multirow{2}{*}{$\begin{array}{c}\text { Race } \\
\text { W }\end{array}$} & \multirow{2}{*}{$\begin{array}{c}\text { M G age- } \\
\text { onset (y) }\end{array}$} & \multirow{2}{*}{$\begin{array}{c}0 \& G \\
\| \mathrm{lb}\end{array}$} & \multirow{2}{*}{$\begin{array}{l}\text { MGFA } \\
\text { III b }\end{array}$} & \multirow{2}{*}{$\begin{array}{l}\text { Anti- } \\
\text { AChR }\end{array}$} & \multirow{2}{*}{$\begin{array}{l}\text { Striational } \\
\text { antibodies }\end{array}$} & \multirow{2}{*}{$\begin{array}{c}\text { Thymus } \\
\text { gland }\end{array}$} & \multirow{2}{*}{$\begin{array}{c}\text { Cycles } \\
1\end{array}$} & \multirow{2}{*}{$\begin{array}{c}\text { Sessions } \\
5\end{array}$} & \multicolumn{3}{|c|}{ Follow-up } \\
\hline & & & & & & & & & & & CSR & $1 y$ & $3 m$ \\
\hline \multirow[t]{2}{*}{2} & $M$ & B & 30 & $\| \mathrm{b}$ & III a & $14,5^{*}$ & neg & Hyperplasia & 1 & 5 & & & \\
\hline & & & & & & & & & 6 & 2 & U & & $8 m$ \\
\hline 3 & M & W & 26 & $\| \mathrm{b}$ & III b & 145 & $1 / 640$ & Thymoma & 1 & 5 & PR & $2 y$ & $3 m$ \\
\hline 4 & M & W & 21 & $\| \mathrm{b}$ & III a & & & Hyperplasia & 1 & 5 & CSR & $1 y$ & $8 m$ \\
\hline 5 & $\mathrm{~F}$ & W & 28 & III & V & 0.13 & & Thymoma & 1 & 4 & PR & $4 y$ & $4 m$ \\
\hline 6 & $F$ & W & 28 & $\| \mathrm{b}$ & III a & & & Normal & 1 & 2 & MM2 & $1 y$ & $6 m$ \\
\hline 7 & $\mathrm{~F}$ & W & 38 & $\| \mathrm{b}$ & III a & Neg & & & 1 & 5 & U & $1 y$ & $10 \mathrm{~m}$ \\
\hline 8 & M & B & 25 & IV & IV b & & & Normal & 1 & 5 & I & $1 y$ & $2 m$ \\
\hline 9 & M & W & 46 & $\| \mathrm{b}$ & III a & & & Normal & 1 & 5 & 1 & $1 y$ & $4 m$ \\
\hline 10 & $F$ & W & 38 & $\| \mathrm{b}$ & III b & & & & 1 & 5 & I & $1 y$ & $2 m$ \\
\hline 11 & $\mathrm{~F}$ & W & 22 & $\| \mathrm{b}$ & III b & 1.92 & & Hyperplasia & 1 & 5 & CSR & $1 y$ & $2 \mathrm{~m}$ \\
\hline 12 & $\mathrm{~F}$ & W & 19 & $\| \mathrm{b}$ & III b & 0.05 & & Hyperplasia & 2 & 5 & I & & $1 \mathrm{~m}$ \\
\hline 13 & $\mathrm{~F}$ & B & 21 & IV & V & $4.49 *$ & & Normal & 1 & 5 & DEATH & $*$ & $5 m$ \\
\hline 14 & $\mathrm{~F}$ & W & 23 & $\| \mathrm{b}$ & III a & 11.5 & & & 1 & 5 & I & & $6 \mathrm{~m}$ \\
\hline 15 & $\mathrm{~F}$ & B & 35 & III & V & & & Normal & 1 & 3 & MM2 & $7 y$ & $3 m$ \\
\hline 16 & $\mathrm{~F}$ & W & 31 & $\| \mathrm{b}$ & III a & & & Hyperplasia & 1 & 5 & CSR & & $13 m$ \\
\hline 17 & $\mathrm{~F}$ & B & 34 & $\| \mathrm{b}$ & III b & & & & 1 & 5 & 1 & & $8 m$ \\
\hline 18 & M & W & 69 & $\| \mathrm{b}$ & III b & 8.53 & $1 / 160$ & & 1 & 5 & MM2 & $7 y$ & $5 m$ \\
\hline \multirow[t]{2}{*}{19} & $F$ & W & 28 & $\| \mathrm{b}$ & III b & & & & 1 & 4 & & & \\
\hline & & & & & & & & & 1 & 5 & I & & $2 m$ \\
\hline 20 & $\mathrm{~F}$ & W & 26 & $\| \mathrm{b}$ & III a & 50.6 & & & 1 & 3 & MM 3 & $1 y$ & $11 \mathrm{~m}$ \\
\hline 21 & $\mathrm{~F}$ & W & 21 & III & V & 0.62 & & Hyperplasia & 1 & 4 & CSR & $5 y$ & $6 \mathrm{~m}$ \\
\hline \multirow[t]{3}{*}{22} & $\mathrm{~F}$ & W & 24 & III & V & 15.7 & & Normal & 1 & 6 & & & \\
\hline & & & & & & & & & 1 & 2 & & & \\
\hline & & & & & & & & & 1 & 4 & MM2 & $2 y$ & $9 m$ \\
\hline 23 & $\mathrm{~F}$ & W & 43 & III & III b & & & & 1 & 3 & MM 3 & & $1 m$ \\
\hline \multirow[t]{3}{*}{24} & M & B & 14 & III & III b & & & Normal & 3 & 5 & & & \\
\hline & & & & & & & & & 1 & 4 & & & \\
\hline & & & & & & & & & 5 & 2 & 1 & $1 y$ & $7 \mathrm{~m}$ \\
\hline 25 & $\mathrm{~F}$ & W & 14 & III & III b & 144 & & Hyperplasia & 1 & 5 & MM 3 & $1 y$ & $1 \mathrm{~m}$ \\
\hline 26 & $\mathrm{~F}$ & B & 11 & III & IV b & & & Hyperplasia & 1 & 5 & MM2 & $1 y$ & $2 m$ \\
\hline
\end{tabular}

of patients for thymectomy.

The first M G patient submitted to PE at Unicamp Clinical Hospital was in 1993 and the present PE series includes about $17.8 \%$ of all M G patients followed-up at the Institution from 1982 to January 2002. The proportion of 2.7:1 for female:male and the demographic characteristics of the group represent the populations attended and the most severely diseased. Clinical manifestations of M $G$ were recorded according to 0 $\& \mathrm{G}$ scale ${ }^{13}$ as $\mathrm{llb}$ (moderate generalized with bulbar signs) in 16 cases, III (acute fulminating) in eight cases, IV (late severe) in two cases. Regarding to M GFA scale ${ }^{4}$, patients were classified as class IIla (moderate weakness predominantly affect- 
ing limb, axial muscle or both and lesser involvement of oropharyngeal muscles) in eight cases; Illb (deficit predominantly oropharyngeal and/or respiratory plus limb and/or axial muscles lesser involved) in 11 cases; IVb (severe weakness predominantly affecting oropharyngeal and/or respiratory muscles, may also have lesser or equal deficit of limb, axial muscles or both) in two and class V (intubated, with or without mechanical ventilation) in five cases. The least severe grade of the disease for which we indicated PE was Ilb according to $O \& G$, corresponding to Illa in the M GFA scale. PE was indicated due to myasthenic crisis in seven cases, $26.9 \%$ of the casuistic. Werneck et al. ${ }^{20}$ used PE as specific treatment in $16.6 \%$ of 24 cases of these potentially fatal condition.

In case $6 \mathrm{PE}$ was performed four days previous to thymectomy for preparing the patient to surgery, as suggested by others $^{17,21,22}$. The patient had difficulty in the maintenance of motor strength while lowering prednisone. As expected postoperative result was uneventful. Dias-Tosta and Fernandes ${ }^{18}$ reported eight patients submitted to $\mathrm{PE}$ : five indicated as prethymectomy in cases with restricted vital capacity and in three cases the procedure was performed after surgery because worsening of motor power.

In 18 cases PE was indicated because severe motor deficit, especially bulbar dysfunction or due to exacerbation of deficit induced by corticosteroid. This drug is the first choice in the therapy of MG, regarding the autoimmune aspects of the disease, but half of the patients may worsen, requiring careful monitoring ${ }^{1}$.

Cases 2 and 24 were submitted to PE also because other therapies failed to achieve the necessary sustained motor performance for daily life activities. They had 6 and 5 cycles of $\mathrm{PE}$ respectively, in a monthly schedule of two consecutive days sessions. Chronic PE was proposed by Kornfeld et al. ${ }^{6}$ as effective therapy in cases of generalized MG refractory to other treatments. Rodnitzky and Bosch ${ }^{5}$ described two cases of intermittent PE therapy prescribed up to five years without significant side effects.

Korach et al. ${ }^{23}$ observed that immediate complications of PE decreased by half in the last 15 years according to the French $P E$ registry. Anticoagulation with sodium citrate solution was responsible for $3 \%$ of side effects in all PE procedures ${ }^{24}$, like perioral tingling, trembling, dizziness and hypotension ${ }^{24,25}$. Hypocalcemia resulted in mild paresthesias and tremor in seven of our patients. Vasovagal attack with concomitant hypotension, true hypovolemia or fluid overload may also be complications of $\mathrm{PE}^{25}$. Hypotension occurred in seven of our 26 patients and was reversed by fluid replacement. In a group of 144 sessions of PE, Wendell Neto et al. ${ }^{19}$ encountered 10.4 $\%$ of paresthesias, $2 \%$ of hypotension and $10,4 \%$ of allergic reactions. Seggia et al. ${ }^{17}$ also presented a list of PE side effects in their patients, all easily managed.
Placement of the central catheter can be the cause of major complications associated with PE, such as pneumothorax, thrombosis or infection ${ }^{24,25}$. Microbiological culture of catheter's extremity was always negative in our patients. In our series there was no death directly related to PE. In case 13 , the patient was a chronic ventilator dependent with diaphragmatic paralysis. She had a prolonged hospitalization, evolving to death from sepsis that occurred five months after PE. Kiprov et al. ${ }^{24}$ found a mortality rate of $0.006 \%$ from two large mobile apheresis services. In a survey of seven years PE in Mexico, the mortality rate was $0.2 \%{ }^{26}$.

In conclusion, acute $\mathrm{PE}$ was a rational treatment for patients with myasthenic crisis and in preparation for thymectomy. It had a favorable short-term impact on severe weakness and exacerbation of symptoms. PE was used in association with prednisone or other immunosuppressor while waiting for further stable improvement or disease remission. On a chronic intermittent basis, PE was indicated for patients who had previously failed to respond to other therapies. In our cases immediate improvement in motor performance was detected, either by a reduction of deficit or a diminution of daily doses of cholinesterase inhibitors and of immunosuppressive drugs.

\section{REFERENCES}

1. Drachaman DB. Myasthenia gravis. N Engl J Med 1994;330:1797-1807.

2. Strauss RG, Ciavarella D, Gilcher RO, et al. An overview of current management. J Clin Apheresis 1993;8:189-194.

3. Assessment of plasmapheresis. Report of the therapeutics and technology assessment subcommittee of the American Academy of Neurology. Neurology 1996;47:840-843.

4. Jaretzki A III , Barohn RJ, Ernstoff RM, et al. Myasthenia gravis: recommendations for clinical research standards. Neurology 2000;55:16-23.

5. Rodnitzky RL, Bosch EP. Chronic long-interval plasma exchange in myasthenia gravis. Arch Neurol 1984;41:715-717.

6. Kornfeld P, Ambinder EP, Mittag T, et al. Plasmapheresis in refractory generalized myasthenia gravis. Arch Neurol 1981;38:478-481.

7. Sanders DB, Andrews IP, Howard JF, Massey JM. Seronegative myasthenia gravis. Neurology 1997: 48(Suppl 5):S40-S45.

8. Newson-Davis J, Pinching AJ, Vincent A, Wilson SG. Function of circulating antibody to acetylcholine receptor in myasthenia gravis: investigation by plasma exchange. Neurology 1978;28:266-272.

9. Newson-Davis J, Vincent A, Wilson SG, Ward CD. Long-term effects of repeated plasma exchange in myasthenia gravis. Lancet 1979;1:464-468.

10. Behan PO, Shakir RA, Simpson JA, Burnett AK, Allan TL, Haase G. Plasma-exchange combined with immunosuppressive therapy in myasthenia gravis. Lancet 1979;1:438-440.

11. Carter B, Harrison R, Lunt GG, Behan PO, Simpson JA. Anti-acetylcholine receptor antibody titers in the sera of myasthenia patients treated with plasma exchange combined with immunosuppressive therapy. J Neurol Neurosurg Psychiatry 1980;43:397-402.

12. Dau PC, Lindstrom JM, Cassel CK, Denys EH, Shev EE, Spitler LE. Plasmapheresis and immunosuppressive drug therapy in myasthenia gravis. N Engl J Med 1977;297:1134-1140.

13. Osserman E, Genkins G. Studies in myasthenia gravis: review of a twenty-year experience in over 1200 patients. Mt Sinai J Med 1971;38:497-537.

14. Pinching AJ, Peters DK. Remission of myasthenia gravis following plasma exchange. Lancet 1976;2:1373-1376.

15. Clark WF, Rock GA, Buskard N et al. Therapeutic plasma exchange: an update from the Canadian Apheresis Group. Ann Intern Med 1999; 131:453-462.

16. Yeh JH, Chiu H C. Therapeutic apheresis in Taiwan. Ther Apher 2001;5:513-516.

17. Seggia JCB, Abreu P, Takatani M. Plasmapheresis as preparatory method for thymectomy in myasthenia gravis. Arq Neuropsiquiatr 1995;53:411-415. 
18. Dias-Tosta E, Fernandes RNM. Miastenia grave: tratamento com timectomia, corticóide e plasmaferese. Arq Neuropsiquiatr 1989;47:39-50.

19. Wendell S Neto, Assis JL, Marchiori PE. Métodos que removem anticorpos e células imunoagressivas: tratamento das crises miastênicas e colinérgicas. In Assis JL (Ed). Miastenia grave. São Paulo Sarvie,; 1990:253-263.

20. Werneck LC, Scola RH, Germiniani FMB, Comerlato EA, Cunha FMB. Myasthenic crisis: report of 24 cases. Arq Neuropsiquiatr 2002;60:519-524.

21. Spence PA, Morin JE, Katz M. Role of plasmapheresis in preparing myasthenic patients for thymectomy. Can J Surg 1984;27:303-304.

22. Empaire G, Hoaglin DC, Perlo VP, Pontoppidan H. Effect of prethymectomy plasma exchange on postoperative respiratory function in myasthenia gravis. J Thorac Cardiovasc Surg 1985;89:592-596.

23. Korach J M, Petitpas D, Paris B et al. Plasma exchange in France: epidemiology 2001. Tranfus Apheresis Sci 2003;29:153-157.

24. Kiprov DD, Golden P, Rohe R, Smith S, Hofmann J, Hunnicutt J. Adverse reactions associated with mobile therapeutic apheresis: analysis of 17,940 procedures. J Clin Apheresis 2001;16:130-133.

25. Shumak KH, Rock GA. Therapeutic plasma exchange. N Eng J Med 1984;310:762-771.

26. Lazo-Langener A, Espinosa-Poblano I, Tirado-Cardenas $\mathrm{N}$ et al. Therapeutic plasma exchange in Mexico: experience from a single institution. Am J Hematol 2002;70:16-21. 